\title{
Ontopsicologia e o nexo ontológico
}

\section{Antonio Meneghetti Outubro, 2012.}

A Ontopsicologia é uma Ciência Humanista contemporânea que é hoje estudada, pesquisada e aplicada por instituições de ensino de diversos países. No quadro das ciências difere-se pelo seu objeto específico: o "nexo ontológico".

As Ciências contemporâneas, como a Sociologia, a Medicina, a Economia, analisam seus objetos de estudo a partir das fenomenologias. Utilizando um Eu cultural, formado pela sociedade, o operador de ciência investiga seu objeto analisando a sua biografia, a sua história, o que outros dizem sobre aquele fato. Estudam o Eu aplicado aos fenômenos, não considerando o Em Si da causalidade.

O problema de base reside no instrumento de conhecimento utilizado em qualquer ciência: o Eu do sujeito, o Eu do operador de ciência. E já a Psicanálise nos diz que essa é apenas uma pequena parte, que o homem, em 70 a $80 \%$, é inconsciente a si mesmo.

O resultado é que os grandes problemas aos quais as ciências se propõem a resolver persistem. A fenomenologia deve ser estudada, e isso já fazemos bem, mas deste modo não chegamos à causalidade do sintoma, do fenômeno, do objeto. Muitos pesquisadores sinalizaram esse limite, em particular o físico Werner Heisenberg e o filósofo Edmund Husserl, que explicitou a crise das ciências europeias (em 1935).

É preciso, portanto, um outro tipo de análise, contemporânea à análise dos fenômenos.

Conhecendo profundamente o panorama das ciências, com uma formação intelectual rara e três doutorados segundo os critérios canônicos das maiores universidades europeias, Antonio Meneghetti vai adiante na pesquisa e cria e aperfeiçoa uma metodologia científica durante dez anos de atividade clínica: a Ontopsicologia.

Essa análise é realizada a partir de informações que já são ativas por natureza intrínseca entre homem e ambiente, homem e objeto de pesquisa. A Ontopsicologia descobriu que existe um link a priori, que vai do operador ao objeto de pesquisa. Essas informações são transportadas por aquilo que Meneghetti definiu Campo Semântico, uma comunicação que nos dá a relação direta entre percepção orgânica e Em Si da causalidade. 
Esse link é baseado na intuição de um núcleo informático, definido por Meneghetti de Em Si ôntico. O Em Si ôntico, ou critério-base, comunica através do Campo Semântico, o qual interage diretamente com a causalidade do objeto. E essa percepção, essa informação ocorre entre o interno do pesquisador e o interno do objeto.

E por que essas informações, que são dadas por natureza, não chegam ao Eu do sujeito?

No interior destes dois conhecimentos, isto é, o critério, o Em Si ôntico, e a sua emanação, a sua ação ad extra, que é o Campo Semântico, Meneghetti descobriu que existe também um alterador constante que denominou Monitor de Deflexão. Esse mecanismo nasce da milenar cultura dos povos. A lógica racional tradicional criou um macrossistema que determinou, também no código linguístico, também em relação a tudo o que é a semiótica de expressão, uma alteração nos processos lógicos da nossa mente.

Substancialmente, nós procuramos adequar, relativizar, acomodar o conhecimento objetivo do Em Si causal, do Em Si ôntico, às exigências racionais da cultura externa, da cultura social, da cultura de massa, da cultura histórica.

Isso criou um standard, um estereótipo, um fixo, que, em vez de dar a exatidão do Em Si da causa, dá a conformidade às lógicas racionais tradicionais.

Através da Metodologia Ontopsicológica, criada e aprimorada por Meneghetti nos últimos 40 anos, descrita em mais de 40 obras e apresentada em diversos congressos científicos no Brasil e no exterior, é possível autenticar o instrumento racional, consentindo a reversibilidade entre Eu e Em Si ôntico.

Temos, portanto, junto a tudo o que dizem as ciências, uma informação a mais, um conhecimento a mais que, cruzado, colocado junto com o outro, nos dá a exatidão do conhecimento racional objetivo.

A Ontopsicologia, no seu modo de fazer, primeiro dá uma reforma de investigação, uma reforma de abordagem ao Eu lógico, isto é, torna preciso o instrumento de investigação da racionalidade sobre o objeto. E isso ocorre sempre com base na indicação, na informação que dá o campo semântico do Em Si ou núcleo da causalidade. Neste ponto, nós temos a competência exata.

Essa formação consente o nexo ontológico entre indivíduo e problema, entre sujeito e objeto. Uma formação passepartout que pode ser operada no interior de qualquer ciência, sendo, portanto, interdisciplinar. 
Preocupando-se com a exatidão do pesquisador, é uma competência que pode ser adaptada em todos os campos, porque diz respeito ao homem. E as ciências são os objetos onde o homem se aplica. Pode ser, então, usada em todas aquelas ciências, em todas aquelas técnicas onde o homem pesquisador estabeleceu, configurou divisões, categorias na ciência. Porém, por mais que nós tenhamos dividido, para entendermos melhor, para sermos mais funcionais ao resultado, permanece sempre essa carência da causalidade primeira.

Ontopsicólogo é, portanto, o especialista na racionalidade com nexo ontológico. Faz o uno, o link entre sujeito e objeto.

A Antonio Meneghetti Faculdade (AMF) oferece a formação que abre essa possibilidade. Coloca a inteligência do técnico, do cientista em conexão com a causalidade da vida, da situação, de efeitos que operam dentro do homem, da natureza, da sociedade. 